\title{
APLIKASI METODA RES-2D UNTUK EKSPLORASI AIR BAWAH TANAH DI DAERAH KARS
}

\author{
Oleh : \\ Agus Kuswanto \\ Pusat Pengkajian dan Penerapan Teknologi Pengembangan Sumberdaya Mineral - BPPT
}

\begin{abstract}
People have long been interested in kars, the typically topograhy in limestone area. There are many spectacular ornament in the caves caused by carbonates presipitates. Among the most common shapes which is be chief attraction for cave visitors is stalactites, stalagmites and columns. Beside of the excitements, kars also have hard problem for people who lived in that area. It is how to find out water for their living. Karst formation, both the surface (dolina, hill, etc) and underground forms (caverns, groundwater conduits, underground streams), appears as conductive zones relative to adjacent undisturbed limestone. Therefore resistivity methode will produce good results if applied to identify dolina, conduits, caverns and structure of geology in kars. The methode describes in this paper is Res-2D with configuration of pole-dipole with area for research are kars in Pacitan and Tulungagung region. Four principal layers can typically be differentiated in a vertical section : near surface (clayey) loam and soil in dolina, dry karstified limestone, conduit \& cave and solid unkarstified limestone. They have contrast of resistivity. Conduits have resistivity value range from 10 to $20 \mathrm{ohmm}$, whereas resistivty of cave is $>1000 \mathrm{ohmm}$. Karstified limestone have resistivity value from 20 to $250 \mathrm{ohmm}$, whereas massive limestone have resistivity > $250 \mathrm{ohmm}$. This paper shows that Res-2D methode can give good contribution in exploration of groundwater in kars area.
\end{abstract}

Kata Kunci : Kars, Res-2D, Conduits

\section{PENDAHULUAN}

\subsection{Latar Belakang}

Kars adalah bentuk morfologi yang terjadi di daerah batugamping. Bentuk kars unik dan tipikal yaitu banyak terdapat bukit-bukit berbentuk melingkar serta lembah-lembah dengan diameter dari ratusan meter hingga puluhan kilometer. Kalau dilihat pada peta topografi, maka akan terlihat bentuk - bentuk garis kontur yang melingkar. Bentuk ini terjadi karena proses pelarutan pada batugamping. Disamping bentuk - bentuk tersebut di atas, yang sangat khas pada daerah kars adalah banyaknya gua-gua baik yang bisa dimasuki orang (lubang gua terdapat di permukaan) maupun gua-gua yang terdapat di bawah permukaan.

Kesulitan mendapatkan air, merupakan masalah umum yang dihadapi penduduk yang tinggal di daerah kars. Mereka mendapatkan air dari telaga-telaga serta mata air yang pada musim kemarau biasanya kering.

Beberapa cara untuk mengatasi masalah kekurangan air di daerah kars antara lain dengan melakukan pemompaan sungai bawah tanah kemudian mendistribusikannya ke desa-desa yang ada disekitar lokasi pemompaan.
Pemanfaatan sungai bawah tanah dalam skala yang besar contohnya adalah pemompaan sungai bawah tanah di Gua Bribin - Gunung Kidul. Seandainya sungai-sungai bawah tanah dapat diidentifikasi dengan baik meliputi alur sungai, lebar dan dalam sungai serta perkiraan debitnya maka masalah kesulitan air di daerah kars dapat diatasi dengan baik.

Pada makalah ini penulis memaparkan hasil riset mendeteksi sungai bawah tanah di daerah kars menggunakan metoda Res-2D. Metoda ini adalah salah satu metoda geofisika dinamis dengan sinyal berupa gelombang listrik yang dialirkan ke bawah permukaan bumi melalui besi elektroda. Dari hasil penelitian dapat diketahui bahwa metoda Res-2D sangat baik untuk mendeteksi keberadaan konduit maupun kantung-kantung air di bawah permukaan. Peralatan yang dipakai adalah Geolistrik Mc. OHM tipe 2115-A dilengkapi dengan Geoscanner 1803-AT. Penelitian berlangsung pada bulan Juli - Agustus 2004 dan bulan Mei 2005.

\subsection{Tujuan Penelitian}

Tujuan penelitian adalah mendeteksi keberadaan air bawah tanah menggunakan metoda Res-2D 


\subsection{Daerah Penelitian}

Daerah penelitian adalah daerah kars di Kabupaten Pacitan bagian selatan khususnya Kecamatan Donorejo dan Kecamatan Pringkuku serta daerah kars di Kabupaten Tulungagung.

\section{METODOLOGI}

\subsection{Prinsip Pengukuran}

Resistivity suatu material didefinisikan sebagai resistansi (tahanan) dari material berbentuk silinder dengan luas penampang $A$ dan panjang $l$. Jika tahanan jenis dari material tersebut adalah $\rho$, maka tahanan yang diberi notasi R, diekspresikan sebagai :

$$
R=(\rho A) / \complement
$$

Satuan $R=$ ohm, satuan $\rho=$ ohmm.

Untuk mendapatkan nilai tahanan jenis $(\rho)$ batuan ataupun material yang ada di bawah permukaan, melalui 2 buah elektroda yang ditancapkan ke permukaan bumi di injeksi arus listrik ke bawah permukaan. Kemudian pada jarak tertentu dari 2 elektroda arus tersebut, diletakkan 2 buah elektroda yang yang berfungsi untuk mengukur beda potensial pada jarak tertentu. Perhatikan Gambar 2. Pada gambar ini diperlihatkan arah aliran arus listrik serta garis equipotensial untuk pengukuran metoda resistivity.

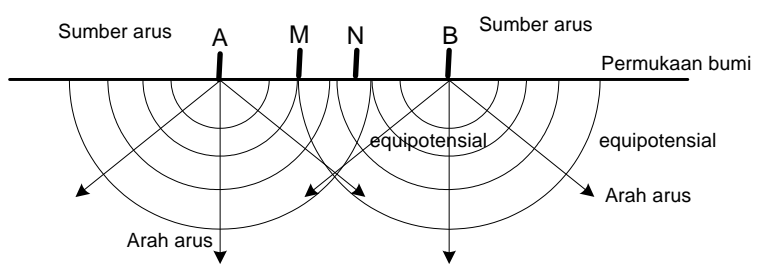

Gambar 2 : Arah aliran arus dan garis equipotensial apabila dua buah elektroda arus yang ditancapkan di permukaan bumi di injeksikan arus listrik.

Medan listrik didefinisikan sebagai E, merupakan fungsi gradien dari potensial. Persamaan dari hubungan ini adalah ${ }^{(1)}$ :

$$
E=-\nabla V
$$

Potensial (V) berkurang $1 / r$ untuk setiap perbedaan jarak dari elektroda arus. Apabila arus I diinjeksikan kebawah permukaan bumi seperti halnya gambar 2, maka beda potensial
(V) di suatu titik pada jarak $r$ dari elektroda arus adalah :

$$
\begin{gathered}
\mathrm{V}=(\mathrm{I} \rho / 2 \pi) \cdot(1 / \mathrm{r}) \\
\rho=(2 \pi)(\mathrm{V} / \mathrm{I}) \cdot(1 / \mathrm{r}) \ldots
\end{gathered}
$$

(1/r) merupakan beda jarak antara elektroda potensial dan arus. Konfigurasi (letak) elektroda arus dan potensial yang berbeda-beda menyebabkan nilai $(1 / r)$ juga berubah-ubah. Dengan demikian, nilai tahanan jenis $(\rho)$ yang didapatkan pada suatu pengukuran tergantung pada nilai $\mathrm{V}$ dan I yang diukur menggunakan alat geolistrik serta posisi elektroda arus dan potensial yang akan mempengaruhi nilai $(1 / r)$.

Pada aplikasi metoda resistivity untuk keperluan air tanah, porositas akuifer dan kandungan kimia air tanah memegang peranan lebih penting dibandingkan conductivity dari butiran mineral/ batuan(1). Apabila rongga antar butir pada batuan terisi air maka yang berperan adalah resistivity air yang disebabkan oleh mekanisme elektrolitik. Dengan demikian berlaku Hukum Archie sebagai berikut :

$$
\begin{aligned}
\rho_{\mathrm{f}} & =a \phi^{-\mathrm{m}} S^{-\mathrm{n}} \rho_{\mathrm{w}} \ldots \ldots \\
\rho_{\mathrm{f}} & =\text { resistivity formasi } \\
\rho_{\mathrm{w}} \quad & =\text { resistivity air }
\end{aligned}
$$$$
\mathrm{n} \cong 2
$$$$
\mathrm{a}=0.6-2.5
$$$$
\mathrm{m} \quad=1.3-2.5
$$

Dengan memperhatikan Hukum Archie tersebut, maka untuk mendapatkan pemodelan yang benar pada pengukuran menggunakan metoda resistivity harus diukur pula nilai resistivity sebenarnya (true resistivity) dari air $\left(\rho_{w}\right)$ yang terdapat di daerah penelitian. Adapun nilai resistivity yang terukur pada metoda resistivity adalah of (resistivity formasi).

Pada metoda Resistivity dikenal metoda pengukuran 1D (disebut Res-1D), 2D (disebut juga Res-2D, ataupun Imaging Resistivity), 3D dan bahkan 4D. Pada Res-1D, hasil interpretasi seperti data bor ; yakni data yang tergambar hanya satu dimensi, merupakan sebaran resistivity pada suatu titik dari kedalaman $0 \mathrm{~m}$ sampai ratusan meter di bawah permukaan.

Sedangkan pada Res-2D hasilnya berupa vertival section (sebuah penampang berupa informasi bawah permukaan yang mempunyai informasi kedalaman dan penyebaran lateral). Tentu saja, hasil Res-2D jauh lebih bagus daripada hasil Res-1D. Pada penerapan praktis, model 1D kurang baik apabila diterapkan pada eksplorasi (5). Dengan berkembangnya metoda numerik dan pemakaian komputer yang semakin canggih, maka selanjutnya metoda Res-2D 
berkembang lebih baik dan lebih cocok untuk daerah dengan geologi yang komplek. Oleh karena alasan inilah maka pada makalah ini dipaparkan hasil penelitian menggunakan metoda Res-2D.

\subsection{Cara Pengukuran}

Pengukuran yang dilakukan pada penelitian di paparkan makalah ini menggunakan metoda Res-2D konfigurasi pole dipole. Susunan elektroda arus dan potensial dapat dilihat pada Gambar 3.

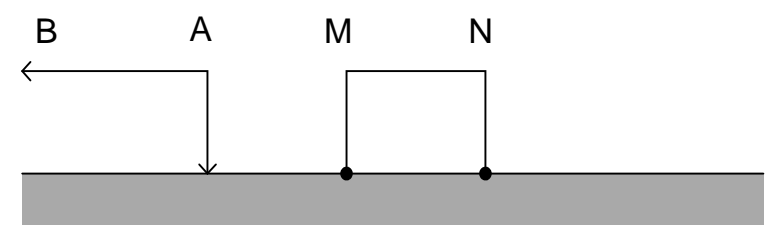

Gambar 3 : Susunan elektroda arus dan potensial pada konfigurasi pole dipole.

Pada Gambar 3, A dan B adalah elektroda arus, $\mathrm{B}$ diletakkan tetap pada jarak tak hingga. $\mathrm{M}$ dan $\mathrm{N}$ adalah elektroda potensial.

Sebaran data hasil pengukuran dapat dilihat pada Gambar 4.

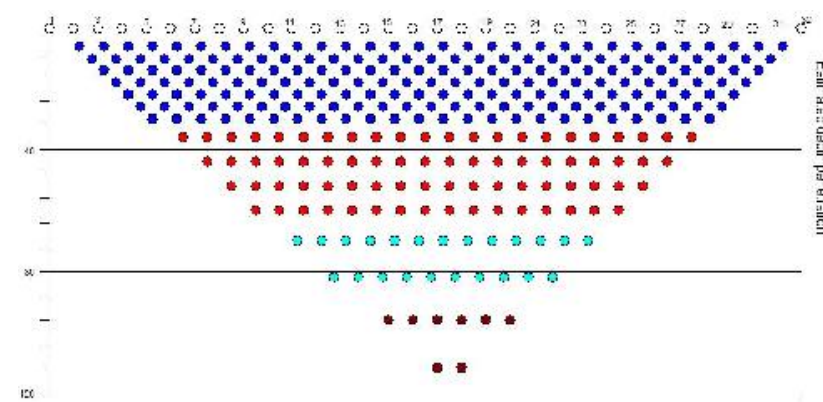

Gambar 4 : Sebaran data pada pengukuran Res2D menggunakan konfigurasi pole - dipole.

Dengan jarak antar elektroda potensial 10 meter, maka kedalaman yang diperoleh pada pengukuran adalah 100 meter di bawah permukaan.

Sebelum dilakukan pengukuran di daerah penelitian, terlebih dahulu dilakukan pengukuran di atas mata air yang ada di daerah tersebut. Di sini, ketinggian serta lebar lubang gua yang berfungsi sebagai mata air dapat diukur. Dengan demikian apabila dilakukan pengukuran resistivity maka bentuk penampang yang dihasilkan dapat dibandingkan langsung dengan keadaan sebenarnya. Pengukuran di atas mata air bisa dijadikan referensi untuk identifikasi sumber air di daerah tersebut.

Disamping dilakukan pengukuran resistivity, air yang mengalir pada mata air juga harus di ambil conto nya (sampled), selanjutnya ditentukan nilai daya hantar listrik (DHL) serta parameter-parameter lainnya.

\subsection{Prinsip Pemodelan}

Hasil yang diperoleh pada pengukuran mencerminkan nilai resistivity semu (pseudoresistivity). Oleh karena itu perlu dilakukan pemodelan untuk mendapatkan nilai resistivity serta kedalaman yang sebenarnya. Dengan demikian nantinya penampang hasil pemodelan dapat mencerminkan penampang bawah permukaan yang mendekati keadaan sebenarnya.

Pemodelan yang digunakan pada makalah ini menggunakan metoda inversi. Inversi data dalam geofisika diartikan sebagai pencocokan anomali yang terukur ke persamaan anomali yang dihasilkan benda penyebab anomali untuk mendapatkan parameter pemodelan. Jadi dalam hal ini model resistivity dan kedalaman untuk setiap lapisan diasumsikan terlebih dahulu, kemudian respons secara teoritis dihitung. Perhitungan yang diperoleh selanjutnya dibandingkan dengan data yang teramati sampai menghasilkan perbedaan yang paling kecil (minimalisasi). Ada kriteria yang berbeda pada proses minimalisasi antara harga teoritis dan pengamatan. Ada yang menggunakan jumlah kuadrat dari selisih antara harga fungsi kernel dari pengamatan dan model , ada pula yang meminimalisasi sumasi $(\Sigma)$ kuadrat dari harga logaritme antara tahanan jenis dan ketebalan untuk setiap lapisan dan respon teoritisnya. Meskipun berbeda, tetapi pada prinsip nya keduanya sama-sama menggunakan kriteria leastquare. Pada makalah ini, metoda leastquare yang dipakai adalah metoda Quasi Newton sebagai pengembangan dari metoda GaussNewton oleh Loke dan Barker (1996) ${ }^{(3)}$. Pada metode ini, pemodelan diawali dengan model bumi homogen kemudian dilanjutkan dengan perhitungan turunan partial matriks Jacobi dan perhitungan finite different.

Pemodelan yang dilakukan pada penelitian ini menggunakan software Res-2D yang dikembangkan oleh M.H. Loke dengan prinsip pemodelan seperti yang diuraikan secara di atas.

Model yang dilakukan pada software tersebut adalah blok segi empat 2D yang besar dan susunannya sesuai dengan sebaran titik data yang ada pada pseudosection (penampang hasil pengukuran geolistrik yang menggambarkan nilai resisitivity dan kedalaman semu). Kedalaman pusat interior blok berada di tengah kedalaman investigasi sedangkan kedalaman investigasi adalah setengah dari spasi elektroda. Leastquare Gauss-Newton diterapkan untuk menghitung resistivity dari blokblok model tersebut. Karena pada penerapan 
leastquare Gauss-Newton matriks Jacobi harus dihitung setiap kali iterasi maka pemodelan memerlukan waktu lama. Untuk mengatasi hal ini, M.H. Loke (1966) (3) menerapkan Leastquare Quasi-Newton. Menggunakan metoda ini, matriks Jacobi tidak perlu dihitung setiap iterasi. Oleh karena itu pemodelan menjadi lebih cepat. Untuk interpretasi dan pemodelan di daerah kars, William E. Kelly dan Stanislav Mares (2) menyebutkan bahwa di daerah kars ada 4 jenis tipe lapisan berdasarkan nilai resistivitynya yaitu : (1) lapisan dekat permukaan, seperti soil, lempungan ataupun dolina dengan nilai resistivity puluhan ohmm, (2) batugamping yang mengalami proses pelarutan (dry karstified) mempunyai nilai tahanan jenis ratusan ohmm, (3) air yang tersimpan pada batugamping kars dengan nilai tahanan jenis puluhan hingga ratusan ohmm (4) batugamping pejal dengan nilai tahanan jenis ribuan ohmm.

\section{HASIL PENELITIAN}

\subsection{Geologi Umum}

Kars adalah suatu bentuk morfologi yang terjadi karena proses pelarutan pada batugamping bioklastik yaitu batugamping yang terbentuk karena pertumbuhan koloni organisme. Proses pelarutan terjadi pada permukaan (eksokars) maupun di bawah permukaan (endokars). Bentuk-bentuk yang terjadi karena eksokars antara lain bentuk bukit yang melingkar, lembah, maupun bentuk batugamping yang runcing-tajam di permukaan. Sedangkan bentuk yang terjadi karena endokars antara lain gua, sungai bawah tanah, dan kantung-kantung air di bawah permukaan.

Di daerah non-kars, air tanah tersimpan di antara butiran batuan lapisan akuifer sedangkan di daerah kars air tanah tersimpan didalam rongga ataupun celah yang disebut juga konduit (saluran).

Daerah penelitian yaitu daerah kars di Kecamatan Donorojo, Pringkuku dan Punung mempunyai luas kurang lebih 345,84 km2. Batuan yang terdapat di daerah ini adalah batugamping terumbu yang termasuk Formasi Wonosari dan batugamping klastik bersisipan napal yang termasuk Formasi Oyo. Kedua batugamping ini berumur Miosen Tengah Pliosen atau sekitar (berumur sekitar 5,3 juta tahun lampau). Batugamping terumbu memberikan kenampakan kars sedangkan batugamping klastik yang umumnya terletak di bawahnya merupakan lapisan batugamping yang pejal dan kedap air.

Sumber air didapatkan dari telaga kars dan mata air kars. Mata air kars merupakan indikasi adanya sistem tata air di bawah permukaan batugamping kars. Di daerah penelitian banyak dijumpai mata air yang muncul ke permukaan karena pemotongan oleh topografi (lekuk lembah maupun pemotongan tebing) dan struktur. Munculnya mata air ini juga bisa terjadi karena stratigrafi daerah setempat.

\subsection{Hasil Pengukuran di Mata Air}

Hasil pengukuran DHL (daya hantar listrik) pada air yang diambil di mata air adalah sebagai berikut :

\begin{tabular}{|l|c|c|}
\hline & $\mathrm{DHL}$ & $\rho \mathrm{w}$ \\
\hline Pacitan-1 & 818 & 12.22494 \\
\hline Pacitan -2 & 505 & 19.80198 \\
\hline Tulungagung & 1350 & 7.407407 \\
\hline
\end{tabular}

Hubungan antara $\rho w$ dan $\rho f$ adalah :

$$
\mathrm{F}=\rho f / \rho \mathrm{w}
$$

dimana ;

$\rho f \quad=$ resistivity formasi

$\rho \mathrm{W} \quad=$ resistivity air

Pada daerah kars, air tidak terdapat pada rongga antar butir seperti halnya pada lapisan akuifer melainkan mengisi rongga batuan. Oleh karena itu nilai $\mathrm{F}$ mendekati angka 1. Dengan demikian berdasarkan hasil perhitungan DHL pada air yang terdapat di beberapa mata air kisaran resistivity air yang seharusnya terlihat pada penampang Res-2D adalah antara $12-20$ ohmm. Khusus untuk mata air di Kab. Tulungagung (mata air song bajul), nilainya 7.4 ohmm. Disamping dilakukan pengukuran langsung resistivity air, dilakukan juga pengukuran Res-2D di atas mata air.

Gambar 5 dan 6 merupakan penampang geologi hasil pemodelan dari pengukuran Res2D di atas mata air. Gambar 5 diperoleh dari pengukuran di atas mata air di Desa Kotlik Kecamatan Donorojo Kabupaten Pacitan Jawa Timur. Mata air keluar dari batugamping terumbu melalui lubang kurang lebih dengan diameter 0.5 meter. Pada musim hujan debit mata air bisa mencapai 5 liter per detik. Tetapi pada musim kemarau jauh berkurang. Ketinggian lubang mata air dari tebing \pm 5 meter .

Hasil pengukuran Res-2D menunjukkan posisi mata air berada pada anomali dengan nilai resistivity $10-20 \mathrm{ohmm}$. Ternyata mata air ini menunjukkan suatu bentuk menerus menyerupai saluran mata air bawah permukaan. Bentuk ini disebut konduit. Bentuk konduit berhenti di meter 6 dan 22. Hal ini bukan menunjukkan bahwa konduit tersebut hanya mempunyai panjang 16 meter saja, melainkan menunjukkan adanya pembelokan arah konduit pada posisi tersebut. Nilai tahanan jenis ini selanjutnya dipakai acuan 
untuk interpretasi dan pemodelan pada hasil pengukuran Res-2D di Kecamatan Donorojo.

Gambar 6 diperoleh dari pengukuran di atas mata air di Sendang Biru Daerah Sedayu Gunung Kabupaten Tulungagung. Nilai tahanan jenis mata air di daerah ini juga berkisar antara $10-20 \mathrm{ohmm}$. Bentuk rongga yang tergambar pada pemodelan ada yang berbentuk melingkar ada yang memanjang. Hal ini menunjukkan bahwa konduit di daerah mata air ini adalah berkelak-kelok. Konduit yang sejajar penampang akan menghasilkan bentuk memanjang sedangkan yang tegak lurus penampang akan menghasilkan bentuk melingkar. Pengukuran Res-2D di mata air ini selanjutnya dipakai acuan untuk melakukan interpertasi dan pemodelan data-data Res-2D di daerah setempat.

\subsection{Hasil Pengukuran di Pemukiman}

Pengukuran selanjutnya dilakukan di pemukiman . Tujuannya adalah untuk mendeteksi sumber air bawah tanah di daerah kars.

Pengukuran dilakukan di Kecamatan Donorojo, Pringkuku dan Punung Kabupaten Pacitan serta beberapa desa di Kabupaten Tulungagung. Pada makalah ini hasil pengukuran Res-2D yang ditampilkan diambil dari desa Kotlik dan Kenasri Kabupaten Pacitan serta Desa Gamping dan Sedayugunung Kabupaten Tulungagung.

Fenomena yang dapat diidentifikasi dari hasil pengukuran Res-2D pada daerah tersebut adalah : bentuk dolina, batugamping terumbu dan klastik, patahan, gua bawah tanah serta sungai bawah tanah.

\subsubsection{Dolina}

Bentuk dolina dapat dilihat pada gambar 7 . Dolina di Amerika dikenal sebagai sinkhole (4) adalah lekuk tertutup pada permukaan batugamping yang mempunyai garis tengah beberapa meter hingga $1 \mathrm{~km}$ dengan kedalaman ratusan meter. Dolina umumnya terisi lapisan tanah, sehingga penduduk memanfaatkannya untuk lahan perkebunan. Pada gambar 7 (Desa Kenasri) dolina teridentifikasi sebagai lapisan dengan kisaran resistivity antara $5-20 \mathrm{ohmm}$, dan terletak di permukaan. Tidak ada dolina di bawah permukaan. Oleh karena itu kalau ada nilai resistivity $5-20$ ohmm tetapi letaknya di bawah permukaan, dapat dipastikan itu bukan dolina.

Dari penampang gambar 7 ini , panjang dolina mencapai 100 meter lebih dengan kedalaman hingga 20 meter.
Batugamping terumbu dapat dibedakan dari batugamping massive (pejal). Batugamping terumbu mempunyai nilai resistivity $20-250$ ohmm sedangkan batugamping pejal (klastik) mempunyai kisaran resistivity di atas $250 \mathrm{ohmm}$. Batugamping pejal ini mempunyai permeabilitas tinggi oleh karena itu dapat berfungsi sebagai lapisan kedap air (4).

\subsubsection{Gua}

Fenomena lain yang menarik adalah bentuk gua di bawah permukaan. Bentuk ini dapat dilihat pada gambar 7, pada penampang geologi daerah Kenasri Pacitan. Gua ini disamping terdeteksi pada penampang geologi hasil pengukuran Res-2D, ternyata pada keadaan sebenarnya juga dapat diketemukan dengan posisi yang tepat. Gua bawah permukaan mempunyai nilai resistivity yang tinggi, di atas 1000 ohmm. Yang menarik, ternyata pada pemodelan Res-2D dapat dibedakan dengan baik antara gua yang kosong, gua yang terisi air sedikit dan gua yang terisi air banyak. Rongga yang terisi air banyak (misalnya sungai bawah tanah) mempunyai kisaran resistivity $10-20$ ohmm. Sedangkan rongga yang terisi air tetapi sedikit (kedalaman air $<5$ $\mathrm{cm}$ ), nilai resistivity nya antara $50-100 \mathrm{ohmm}$, sedangkan rongga kosong (misalnya gua) nilai resistivity nya $>1000$ ohmm.

Pada penampang geologi Kenasri (gambar 7) di bawah gua terdapat aliran sungai bawah tanah yaitu di sekitar kedalaman 40 meter di bawah permukaan tanah.

Hanang Samodra (4) menyebutkan bahwa bentuk rongga di daerah kars merupakan bentuk yang unik dan rumit. Rongga - rongga bisa saling berhubungan mulai dari yang kecil kemudian menyambung ke rongga lainnya yang lebih besar. Bentuk rongga ini bisa miring, horisontal maupun vertikal. Rongga yang kecil berupa celah sempit di batugamping terumbu tidak dapat terdeteksi oleh pengukuran Res-2D pada makalah ini. Hal ini terjadi karena pengukuran Res-2D pada makalah ini menggunakan spasi elektroda 5 dan 10 meter. Menggunakan spasi 5 meter, lebar rongga yang bisa terdeteksi minimal 2,5 meter. Lebih kecil dari 2,5 meter tidak akan terlihat.

Jadi, kalau ingin mendeteksi rongga atau celah sempit yang berukuran $10 \mathrm{~cm}$ misalnya, maka spasi elektroda yang dipergunakan seharusnya $20 \mathrm{~cm}$. 


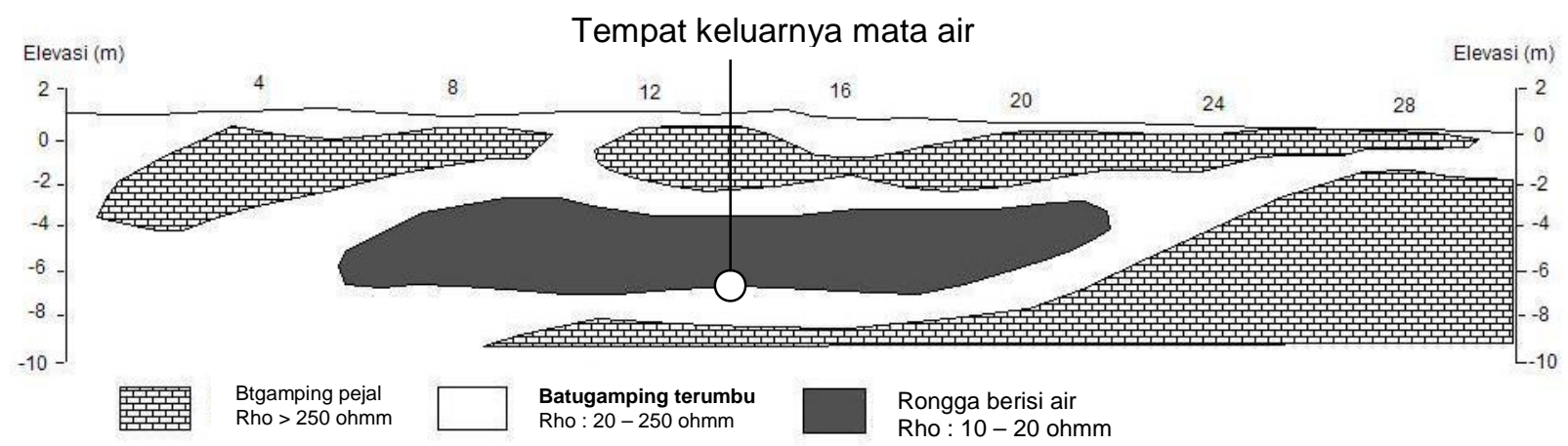

Gamabar 5 : Penampang geologi hasil pemodelan menggunakan Res-2D. Pengukuran dilakukan di atas mata air kars di Desa Kotlik Kabupaten Pacitan Jawa Timur

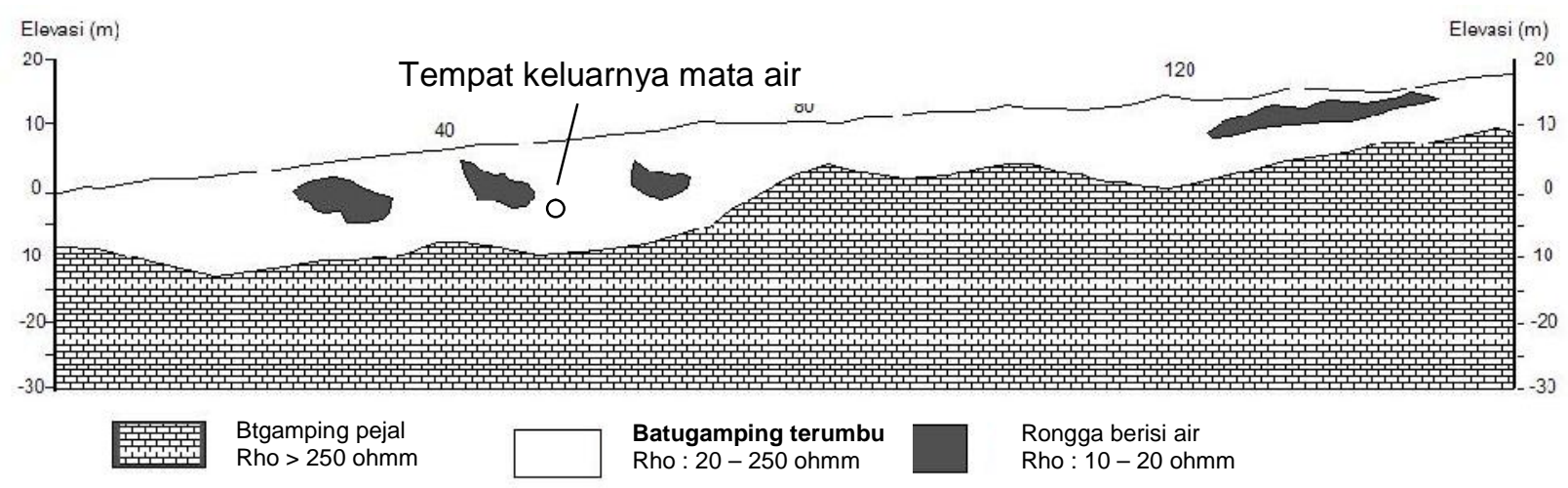

Gambar 6: Penampang geologi hasil pemodelan menggunakan Res-2D. Pengukuran dilakukan di atas mata air kars di Sendang Biru - Sedayu gunung Kabupaten Tulungagung Jawa Timur

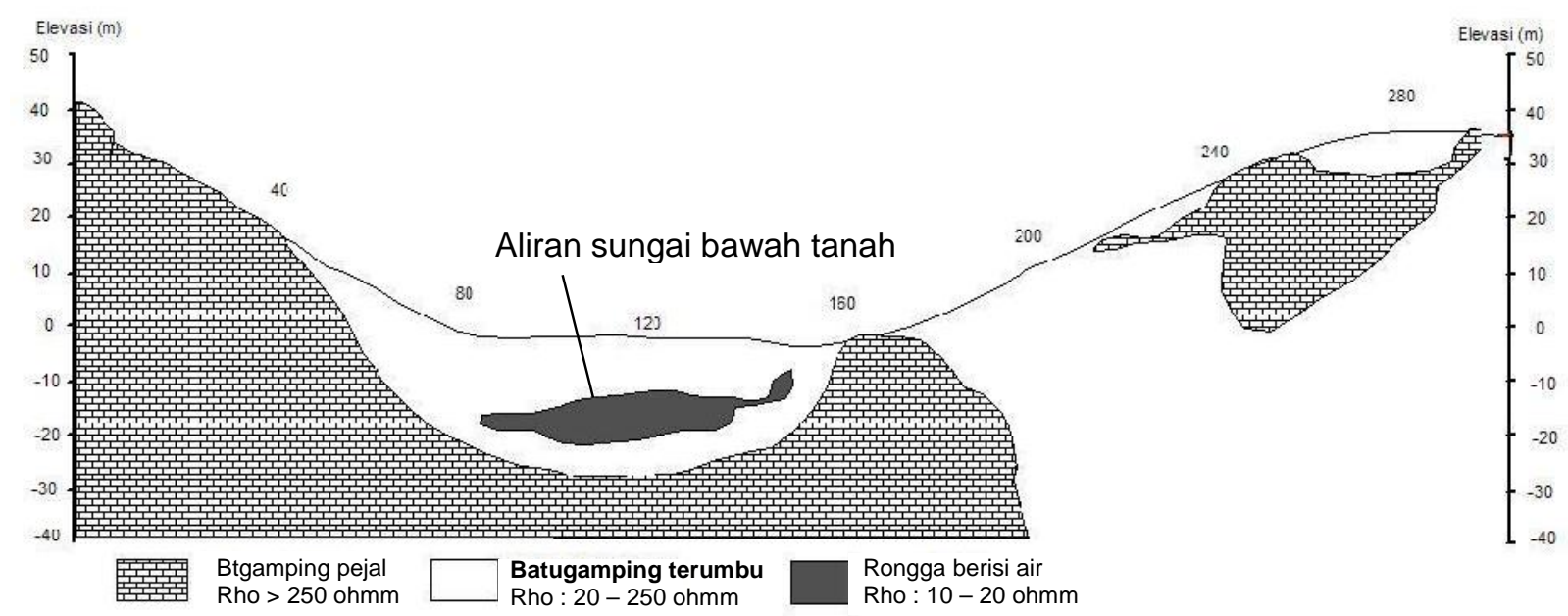

Gambar 6 : Penampang geologi hasil pemodelan menggunakan Res-2D. Pengukuran dilakukan di pemukiman di Desa Kotlik Kecamatan Donorojo Kabupaten Pacitan Jawa Timur 


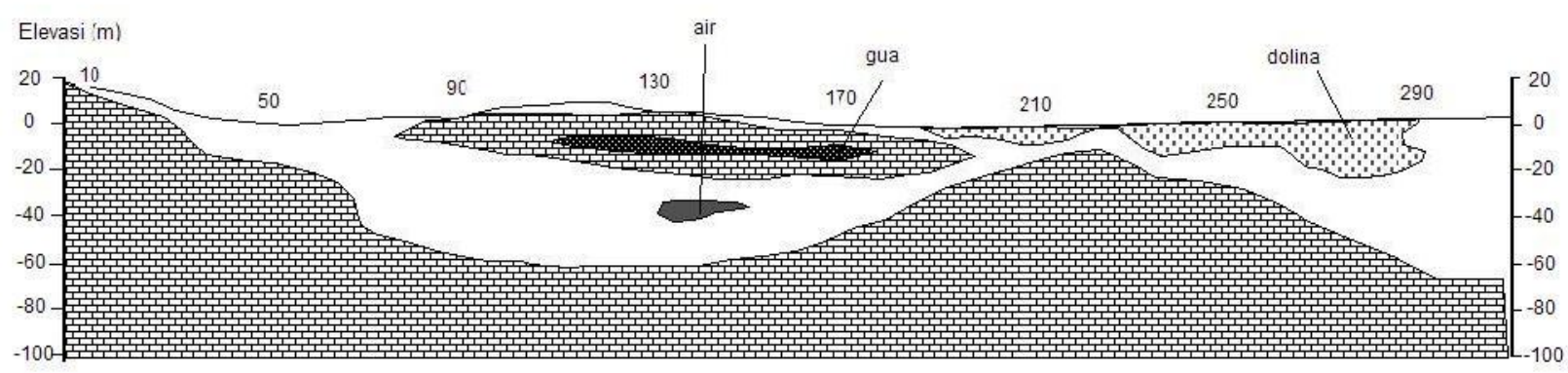

Gambar 7 : Penampang geologi hasil pemodelan menggunakan Res-2D. Pengukuran dilakukan di pemukiman di desa Kenasri Kabupaten Pacitan Jawa Timur. Pada penampang ini tergambar juga dolina, gua bawah tanah serta rongga berisi air.

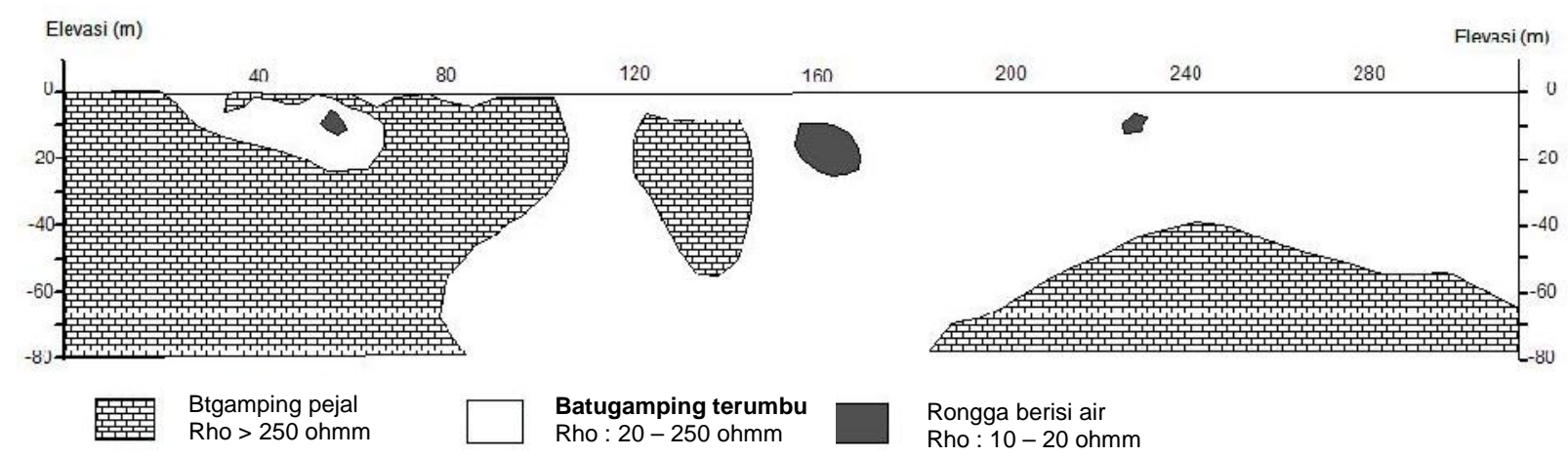

Gambar 8 : Penampang geologi hasil pemodelan menggunakan Res-2D. Pengukuran dilakukan di pemukiman di desa Gamping Kabupaten Tulungagung Jawa Timur.

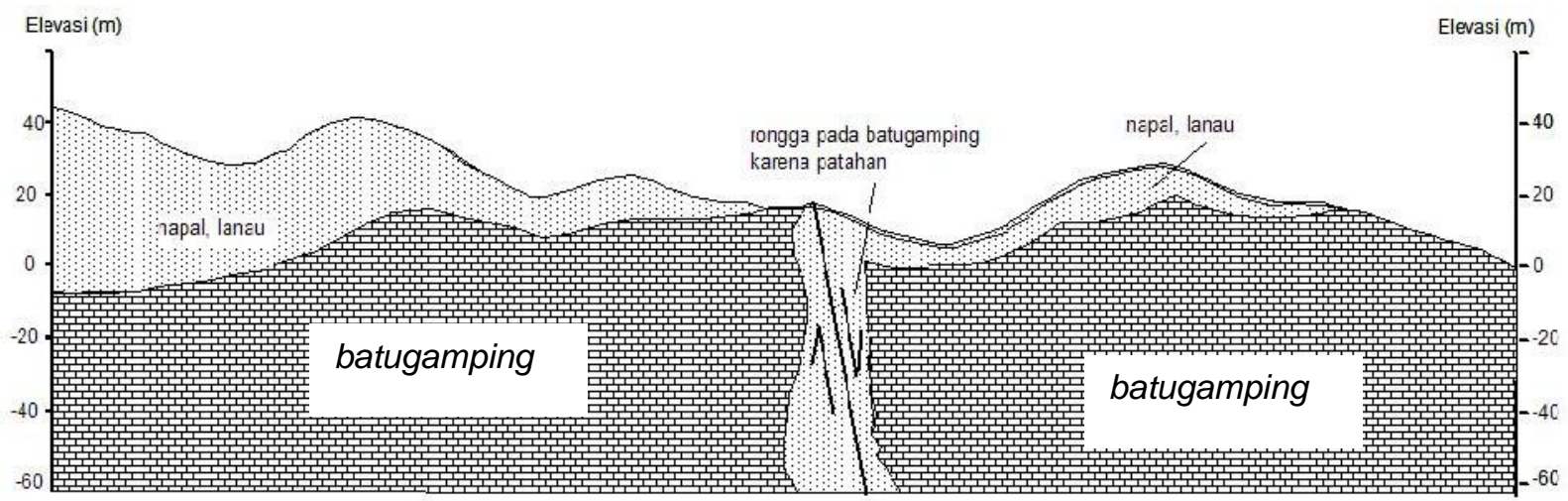

Gambar 9 : Penampang geologi hasil pemodelan menggunakan Res-2D. Pengukuran dilakukan di pemukiman di desa Sedayugunung Kabupaten Tulungagung Jawa Timur. Perhatikan bentuk rongga yang terjadi karena patahan. 
Tetapi yang perlu diperhatikan bahwa spasi elektroda juga mempengaruhi kedalaman penampang geologi yang diperoleh. Kalau menggunakan spasi elektroda $10 \mathrm{~m}$ kedalaman yang diperoleh mencapai $100 \mathrm{~m}$, menggunakan spasi 5 meter kedalaman yang diperoleh mencapai 50 meter, sedangkan apabila menggunakan spasi $20 \mathrm{~cm}$ maka kedalaman yang diperoleh hanya 2 meter.

\subsubsection{Konduit}

Rongga yang menjadi sumber air bawah tanah di daerah kars bisa berbentuk konduit (saluran) yang membentuk sungai bawah tanah, bisa juga hanya berupa kantung-kantung air .

Di Desa Kotlik (Gambar 6), bentuk yang diinterpretasi sebagai konduit terdapat pada kedalaman $10-20$ meter. Pada penampang tersebut panjang konduit yang terdeteksi mencapai 100 meter. Selanjutnya pada meter ke 80 berbelok ke arah lain. Melihat dari bentuk konduit tersebut maka air bawah tanah ini sangat potensial untuk dibor dan dimanfaatkan bagi masyarakat setempat.

Bentuk alur yang menyerupai sungai bawah tanah juga didapati pada penampang geologi Desa Kenasri (Gambar 7). Namun alur yang terdeteksi hanya kurang lebih 20 meter. Perlu dilakukan pengukuran pada lintasan lintasan yang sejajar dengan lintasan ini dengan tujuan untuk melakukan penelusuran arah penyebaran dan bentuk alur.

Air bawah tanah di Desa Kenasri juga potensial untuk dibor dan dimanfaatkan bagi masyarakat setempat. Kendala yang dihadapi pada saat pemboran adalah adanya rongga (gua) di atas konduit. Rongga terletak pada kedalaman 25 meter sedangkan konduit pada kedalaman sekitar 40 meter. Pada saat melewati rongga ini, pemboran akan memerlukan air dalam jumlah banyak. Disamping itu kecepatan pemboran juga akan menurun drastis. Dua hal ini otomatis mempengaruhi jumlah biaya yang diperlukan untuk operasional pemboran.

Penampang hasil pemodelan untuk Desa Gamping (Gambar 8) menunjukkan pada kedalaman 10 sampai 20 meter terdapat 3 (tiga) bentuk rongga yang terisi air. Kalau hanya melihat bentuknya yang melingkar, bisa diartikan sebagai kantung air saja. Tetapi mengingat pada jarak sekitar 300 meter dijumpai mata air, tidak menutup kemungkinan salah satu dari tiga rongga tersebut merupakan rongga saluran yang menerus hingga mata air. Sebagai ilustrasi perhatikan Gambar 10.

Sebatang pipa yang panjang kalau diiris sejajar pipa (bidang iris 1) akan memperlihatkan bentuk memanjang. Tetapi kalau dipotong pada arah melintang (bidang iris 2) maka bentuk yang muncul adalah melingkar.

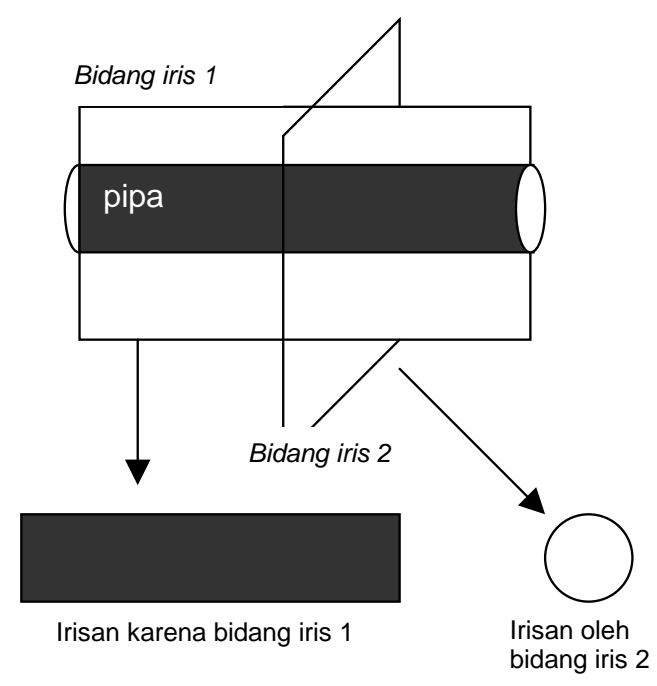

Gambar 10. Ilustrasi hasil irisan pada pipa yang memanjang dengan arah irisan yang berbeda.

Begitu halnya dengan saluran di bawah permukaan. Apabila arah lintasan pengukuran Res-2D sejajar saluran maka hasil yang tergambar bentuk salurannya memanjang. Tetapi apabila arah lintasan pengukuran Res-2D memotong saluran pada arah yang sama dengan bidang iris 2 maka hasilnya melingkar.

Oleh karena fenomena yang demikian maka apabila pada suatu survei menggunakan metoda Res-2D mendapatkan bentuk saluran bawah permukaan disarankan untuk melakukan lintasan pengukuran lagi minimal 3 (tiga) lintasan pada arah yang sejajar lintasan pertama, supaya dapat diketahui dengan pasti apakah rongga yang ditemukan tersebut merupakan rongga suatu konduit atau suatu kantung saja.

Sumber air bawah tanah di Desa Gamping (gb.8) juga potensial untuk dimanfaatkan bagi masyarakat setempat.

\subsubsection{Patahan}

Patahan yang terjadi pada batugamping terumbu tidak hanya menggeser lapisan tetapi lambat laun bisa berkembang menjadi suatu rongga.

Pada pengukuran Res-2D di Desa Sedayugunung (gb.9) dapat diamati adanya patahan turun (patahan normal) yang terjadi pada batugamping. Akibat patahan ini lapisan napal, lanau yang terletak di atas batugamping mengalami penurunan kurang lebih 10 meter. Nilai resistivity pada bidang patahan berkisar antara $10-20$ ohmm. Ini menunjukkan bahwa bidang patahan yang sudah berkembang 
menjadi rongga ini merupakan rongga yang lembab, dan besar kemungkinan menjadi jalur yang dilalui air menuju suatu konduit di bawahnya.

\section{KESIMPULAN DAN SARAN}

\subsection{Kesimpulan}

Metoda Res-2D merupakan metoda yang lebih baik dibandingkan geolistrik sounding (geolistrik 1D), karena Res-2D lebih realistis dalam menggambarkan bentuk bawah permukaan. Oleh karena itu Res-2D bisa diterapkan di daerah dengan geologi yang rumit (banyak struktur geologi) serta di daerah kars.

Nilai resistivity batugamping massive (pejal) adalah > 250 ohmm dan untuk batugamping terumbu berkisar antara $20-250$ ohmm. Ada 3 (tiga) macam rongga di bawah permukaan yakni rongga yang kosong, ditunjukkan dengan nilai resistivity di atas 1000 ohmm, rongga yang terisi air tetapi sedikit ditunjukkan dengan nilai resistivity antara 50 hingga 100 ohmm dan rongga yang terisi air lebih banyak dengan nilai resistivity antara $10-$ 20 ohmm. Rongga dengan kisaran $10-20$ ohmm inilah yang potensial sebagai sumber air bawah tanah. Untuk menentukan debit air harus dilakukan penelusuran rongga ; apakah menerus berupa suatu konduit atau hanya suatu kantung saja. Cara penelusuran adalah dengan membuat lintasan pengukuran geolistrik lebih dari tiga dan lintasan tersebut dibuat berjajar .

Disamping batugamping dan rongga, Res2D juga dapat mengidentifikasi bentuk dolina dan patahan di batugamping. Keduanya menunjukkan kisaran nilai resistivity antara 1 20 ohmm.

Mengingat bahwa di daerah kars air mengalir pada suatu konduit maka nilai $F$ pada persamaan (6) akan menunjukkan angka 1 atau mendekati 1 . Artinya nilai resistivity formasi dan resistivity air relatif sama. Pada daerah non-kars dimana air mengalir pada suatu lapisan akuifer, nilai $\mathrm{F}$ tergantung pada jenis lapisan akuifernya.

Pada daerah yang dipaparkan pada makalah ini, daerah yang potensi sumber air bawah tanahnya dapat dieksploitasi adalah daerah Kotlik (gb. 6), Kenasri (gb.7) dan Gamping (gb.8).

\subsection{Saran}

Untuk menentukan potensi air bawah tanah lebih lanjut, disarankan untuk dilakukan pengukuran lanjutan dengan lintasan minimal 3 (tiga) jalur, berjajar lintasan pertama. Dengan demikian dapat ditelusuri apakah rongga yang tergambar pada lintasan pertama (gb. $6 \mathrm{~s} . \mathrm{d} \mathrm{gb.8)}$ merupakan rongga dari suatu konduit, atau hanya suatu kantung air saja.
Pemanfaatan sungai bawah tanah dengan cara seperti Gua Bribin - Gunung Kidul memang sangat baik untuk mengatasi masalah kekeringan di daerah kars. Namun untuk daerah yang belum menemukan potensi sungai bawah tanah seperti halnya Gua Bribin, dapat memulai nya dengan skala yang lebih kecil. Misalnya mencari konduit bawah tanah kemudian dilakukan pemompaan dengan pompa biasa (bukan submersible pump). Memang cara ini hanya dapat untuk memenuhi beberapa keluarga saja, namun apabila dilakukan di banyak tempat maka bisa untuk mengatasi masalah kekurangan air dalam cakupan wilayah yang luas.

\section{DAFTAR PUSTAKA}

1. Dobrin, M.B., Carl H. Savit. 1988. Introduction to Geophysical Prospecting, Mc.Graw-Hill Book Co., Singapore

2. Kelly W.E., Stanislav Mares, 1993. Applied Geophyisics in Hydrogeological and Engineering Practice, Development in Water Science, Elsevier, Netherland

3. Loke,M.H., R.D. Barker, Rapid Leastquare Inversion of Apparent Resistivity Pseudosection, Geophysics, 1995, vol.60, no.6, p.1682-1690

4. Samodra, H. 2001. Nilai Strategis Kawasan Kars di Indonesia : Pengelolaan dan Perlindungannya, Pusat Penelitian dan Pengembangan Geologi, Bandung

5. Tripp, A.C., G.W. Hohmant, C.M. Swift, Jr., Two Dimensional Resistivity Inversion, Geophysics, 1984 , vol. 49 , no. 49 , no. 10 , p. $1708-1717$ 